\title{
A Tortuous Path of Awakening, an Arduous Quest for Liberation Weiwei Qu
}

Teaching and Research Institute of Foreign Languages, Bohai University, Jinzhou, 121013, China syquwei@yeah.net

Keywords: Kate Chopin; awakening; feminist; liberation

\begin{abstract}
In her The Awakening, the American feminist writer Kate Chopin characterizes such a woman heroine-Edna, who is not satisfied with the role of being a good mother and nice wife. She gradually feels her life's vitality, experiences the power of her sexuality, and craves for the enjoyment of freedom. However, despite the positive steps proceed with Edna's gradual awakening, powerful social forces are arrayed against her. Unable to find a way to translate her spiritual awareness of her freedom into reality, Edna surrenders and stops struggling, committing suicide in the sea. The ambiguous and tragic ending seems to reflect Chopin's view that the patch to women's liberation in male-centered society is far more difficult and complex. Women's liberation is not only the business women, but also the business of the whole human race.
\end{abstract}

\section{Introduction}

The Awakening is Chopin's best known psychological novel, which depicts a woman's search for spiritual and sexual freedom in the repressive society of nineteenth-century America. The protagonist, Edna Pontellier is awakened by the people on the Grand Isle. Dissatisfied with her marriage and the conservative life as a devoted wife and a mother, she gradually searches for her physical, sexual, social and spiritual freedom. However, without anyone understanding and supporting her quest, she becomes hopeless, despair and chooses death as the only solution. It could be seen from Edna's tragedy after her awakening that it is impossible for a woman to pursue her independence and liberation in a male-centered society.

\section{Environment for Edna's Awakening: Natural Environment \& Social Conditions}

In her day, Chopin was regarded as one of many popular local colorists noted more for skillful regional depiction than for insight into human nature. Critics now attach more importance to her work, particularly The Awakening, praising her psychological realism, astute characterization, and careful attention to detail. After being neglected in the early twentieth century, Chopin's works were reassessed and began to receive serious critical attention in the late 1950s.

Edna's awakening begins from her childhood, when Edna "lived her own small life all within herself. At a very early period she had apprehended instinctively the dual life - that outward existence which conforms, the inward life which question" [1]. The first thing encourages the breakdown of the conforming patterns of Edna's outward life is the setting-Grand Isle. It is a Creole summer resort-a place of hot sun enveloped by sea breezes from the Gulf and the place of Creole spontaneity and candor. From the whole scene, we see it is a place full of relax and lazy air as well as the luscious charm of the summer. Besides these natural scenery, we could notice that Madame Lebrun's pension on Grand Isle is very much a woman's land, not only because it is owned and run by a single woman and dominated by "mother-women", but also because its principal inhabitants are actually women and children whose husbands and fathers visit only on weekends [2]. No wonder, during that summer at Grand Isle, Edna "had begun to loosen a little the mantle of reserve that had always enveloped her" [1].

\section{The Causes for Edna's Awakening}

(1) Adele opens Edna's mind and awakens her sense of self. Edna begins her awakening just during 
this summer at Grand Isle. Her first real moment of openness comes during her walk to the beach with Adele Ratignolle. When Adele touches Edna as they sit on the beach, Edna suddenly opens and begins to talk of her childhood "sea of grass" memories. For the first time, Edna risks genuine connection with others. In her initial response to Adele, "Edna awakens to two facts of her own character: her artistic temperament and responsiveness to beauty and her own feminine sensuousness" [3]. Adele is a true representative of femininity. She is excessively devoted to her husband and to her children. She serves both as contrast and catalyst to Edna's growing self-awareness. Edna's goal is two- fold after her introspective time with Adele. In the first place, she becomes aware of her need for freedom. She desires the liberty to choose and to follow her own soul's direction. In the second place, she wishes to be aware of the of her soul, to make choices based upon what she discovers to be her own needs. Adele understands Edna well enough to reach her deepest feelings, to warn Robert to be careful, and to support Edna's efforts to become an artist.

(2) Reisz releases Edna's emotion and awakens her sensuousness. Edna's second moment of emotional release comes from the music of Mademoiselle Reisz. Reisz is a musician devoted solely to art. She is "a homely woman, with a small weakened face and body and eyes that glowed. She had absolutely no taste in dress." [1] She is unmarried, despises children and behaves rudely to everyone. It could be said that Reisz achieves independence through her art. She knows that Edna is the only person on Grand Island who understands and appreciates her music and advises Edna to devote herself to her art, to be strong and to believe in herself. Thus, Edna becomes conscious that "the very passions themselves daily beat upon her splendid body" [1].

(3) Robert sparks Edna's awakening in the passion of her body. Edna's awakening is also sparked by Robert. He encourages her to learn to swim and thus opens her to the sea in which she discovers the infinity of her soul as well as the sensuality of her body. Their conversations prompt her to think about the meaning of her life. He also awakens her to "the passions of her body and the capacity for full sexual experience" [4]. Like the bird's flying images in the novel, swimming also represents reborn, freedom, and wholeness to Edna for it requires overcoming the split she feels between her mind and her body, between thought and feeling, and between conception and acts. "The union of body and soul that comes with her oneness with the sea gives Edna courage and a sense of independence; and her dormant sexuality is finally awakened when she feels the power of her own body" [5].

(4) Arobin triggers Edna's insight about sexuality. Edna realizes the control of sexuality on her when she kisses Alcee Arobin. Though Edna is sure that the one she loved is Robert, she can't help making sexual responses to the luring of Arobin. She submits to the flirting or the playboy whom she does not love at all, but she could not understand the natural force that "pushes" her to do so. Edna has an insight about sexuality after her affair with Arobin. She realizes that sex and love can be separated, so she separates her sexual need from feelings for Robert in order to have an outlet for all her spent-up desire.

\section{Opposing Forces Against Edna's Quest}

Despite the positive steps proceed with Edna's gradual awakening, powerful social forces are arrayed against her. There is no one who understands and support her. Even the two women characters Reisz and Adele who contribute to Edna's awakening could not after Edna what she needs. "Adele, the wife and mother, is without a self; Reisz, the celebrate artist, is without passion" [3]. The two women characters represent the extremes of personality which for Edna are impossible. for Adele, complacent satisfaction-never being alone-comes from having no identity beyond her given roles; while for Reisz, the ambiguous satisfaction of having her own identity is the result of always being alone [6]. Edna is caught between the chains of "mother-woman" and those of "artist-women." Since Edna is seeking for a total awakening, she can't accept a view of art or self as isolating and consuming. In this sense, we could say that the two women characters prevent Edna from realizing her dreams.

Another opposing force against Edna's quest comes from her family members. Edna's husband opposes her newly expressed willfulness. He is puzzled about Edna's notions that she has recently 
acquired-concerning the eternal rights of women. Leonce claims that his wife "dose not act well. She is odd, she is not like herself." "She has abandoned her Tuesdays at home, has thrown over all her acquaintances, and goes tramping about by herself, getting in after dark" [1]. Edna's father is another opposing force. He threatens that neither of Edna's sisters will speak to her any more nor he advise Leonce to use authority and coercion on Edna. According to him, they are the only way to manage a wife. Besides, there is the unresolved question of the children. They are away with grandparents for the summer, but eventually they must return. Their presence challenges Edna's independence and unconventional behavior. Though Edna says that she will not sacrifice herself for her children, she has not considered whether she would be willing to sacrifice their future happiness for her own. Edna can reject the social role of "mother-woman," but she can never escape her biological connection to her sons.

Most heartbreaking force comes from Robert-Edna's true lover. Edna's love for Robert has helped together through the profound loneliness inherent in her radical departures from Creole life. Yet Robert, whose social and personal belief is that Creole can hardly be expected to choose Edna. He loves and wants Edna, but he cannot bring himself to join her in rebellion against the sacrament of marriage. Worse than that, he does not understand Edna. "Robert is Kate Chopin's example of the ordinary man who cannot tolerate the unusual woman, and his reactions emphasize the reasoning which-leads Edna to her final exertions of responsibility and of her will as she pays the price of freedom" [7].

\section{Tragedy After Edna's Awakening}

When Edna concedes to herself that she cannot achieve either autonomy or connection with others, she surrenders and stops struggling. She has awakened to consciousness from a life-long dream only to find her reality a nightmare. She can think of only one way to assert her autonomy, and to become absolutely herself, that is suicide. Because Edna is totally alone at the end with no one understanding her desire to redefine herself outside of traditional societal role for women and no one meeting her newly felt needs. She is unwitting to compromise, and could not bear any more time to sustain her through such unbearable alienation, thus, she chooses to return to the womb-like embrace of the sea [5]. Though it could be said that Edna's suicide is a spiritual triumph after gradual awakening, but it is also a social defeat in that by choosing death, she admits that she cannot find a way to translate her spiritual awareness of her freedom into reality.

The Awakening is a tragic novel. The tragedy lies not only in Edna's death, but also in the failure of realizing the integrity of the spiritual and social quests Edna seeks after her gradual awakenings. This ambiguous and tragic ending seems to reflect Chopin's view that the patch to women's liberation in male-centered society is far more difficult and complex. Women's liberation is not only the business women, but also the business of the whole human race.

\section{The Image of Bird}

Chopin calls for spiritual and physical independence, freedom and self-consciousness of women. In her vivid description, Chopin tries to make women speak, find their voice, and reflect their self-independence and self-development. However, the whole society doubted women's liberation. At the time when The Awakening was published in New Orleans, women were still the possessions of men, and the request for women's sexual morality was really high. Thus, Chopin never criticizes the traditional culture openly and expresses her views directly and openly. What she could do is to use a number of obscure symbols to reflect women's pursuit of self-awareness and self- fulfillment in the repressive society of the late-nineteenth century America. One of the most typical symbolic image in this novel is bird.

When birds are mentioned, people usually think that they can lift them far and high to enjoy freedom due to the wings. However, birds appear in Chopin's The Awakening are not free to fly at the very beginning. The novel begins with the image of caged birds- Madame Lebrun's parrot and a mocking-bird, which are not able to make their own voice but imitate others to express themselves 
and rely on others to feed. In fact, the parrot and mocking bird represent Edna and Mademoiselle Reisz respectively. The parrot could speak some languages, but none of them could be understood by anyone except one by the mocking-bird. The parrot is likely to represent Edna in her initial situation. At that time Edna is a typical oppressed women at home-obedient, numb and dependent on her husband, who is always too busy to care about her. She is anxious for her own independence and try to express herself by her own voice, but nobody could or would like to listen to and understand her except the mocking-bird. While the mocking bird represents Mademoiselle Reisz who also pursues the spiritual independence. She is the only one who could understand Edna's inner feeling and encourage her to seek independence and freedom. Like the birds, the women's movements are confronted with a number of social conventions, customs and the generally acknowledged rules in the repressive society of the late-nineteenth century America. Women were unable to communicate with the world around them. The wings of the two birds are not boosters for flying, but shields for protection. The novel's "winged" women could only use their wings to protect and shield, never to fly.

Edna's desire begins to uncover after a heart-to-heart talk with Adele, The image of "a distant bird winging its flight away"[1] implies Edna's awakening and her hope of seeking independence and freedom. Nevertheless, the bird soon flies away, which implies that Edna's dream of selfhood is just a flash in the pan, and her pursuit of freedom would end up with failure. Edna strives to escape from the fetters of family life and traditional conventions, yet still, she has no chance to get away as her efforts only land her in another cage: the pigeon house. Pigeon is considered as a half-free and half-domestic bird, and this symbol hints that Edna's independence is not complete. While Edna views her new home as a sign of her independence, the pigeon house represents her inability to remove herself from her former life for "her move takes her just two steps away "[1]. Mademoiselle Reisz warns Edna that she must have strong wings in order to survive the difficulties she will face if she plans to act on her love for Robert. "The bird that would soar above the level plain of tradition and prejudice must have strong wings. It is a sad spectacle to see the weaklings bruised, exhausted, fluttering back to earth. "[1] However, apparently, Edna's "wings" are not strong enough to fly further and higher. At the end of the novel, when Edna returns to the sea, the bird appears again "A bird with broken wing was beating the air above, reeling, fluttering, circling disabled down, down to the water." [1] The image implies that Edna's beautiful dreams can never come true. All her hopes dash into pieces, and the only way to release herself is nothing but death. The ambiguous and tragic ending seems to reflect Chopin's view that the patch to women's liberation in male-centered society is far more difficult.

\section{Conclusion}

Edna's tragedy bears the stamp of its time, but it also has enlightenment to women in modern society. Though the living situation of modern people, especially women, is much better than that of Chopin's era, the phenomenon of gender inequality still exists in some parts of the world. Especially, modern women are facing the more severe conflict between individuality and marriage responsibility as wives and mothers. Therefore, the Awaking of women not only requires our striving, but also the endeavor of the whole society.

\section{References}

[1] Chopin, Kate. The Awakening. New York: Bantam Books, 1981.

[2] Gilbert, Sandra M. "The Second Coming of Aphrodite." Modern Critical Views: Kate Chopin. Ed. Harold Bloom. New York: Chelsea House Publishers, 1986. 89-114.

[3] Elble, Kenneth. "A Forgotten Novel." Modern Critical Views: Kate Chopin. Ed. Harold Bloom. New York: Chelsea House Publishers, 1986. 7-16. 
[4] Rosowski, Susan J. "The Novel of Awakening." Modern Critical Views: Kate Chopin. Ed. Harold Bloom. New York: Chelsea House Publishers, 1986. 43-60.

[5] Bogarad, Carley R. "'The Awakening': A Refusal to Compromise." Twentieth-Century Literary Criticism. Ed. Sharon K. Hall. Vol. 5. Detroit: Gale Research Company, 1982. 158-161.

[6] Justus, James H. "The Emotional Withdrawl of Edna Pontellier." Twentieth-Century Literary Criticism. Ed. Dennis Poupard. Vol. 14. Detroit: Gale Research Company, 1984. 72-77.

[7] Rosen, Kenneth M. "Kate Chopin's 'The Awakening': Ambiguity as Art." Journal of American Studies 2 August 1971: 197-99. 